\title{
O TRWALYM ROZWOJU
}

ŚLĄSKI

PRZEGLĄD

STATYSTYCZNY

Walenty Ostasiewicz

Nr 13(19)

Uniwersytet Ekonomiczny we Wrocławiu

ISSN 1644-6739

e-ISSN 2449-9765

DOI: $10.15611 /$ sps.2015.13.13

\begin{abstract}
Streszczenie: Niniejszy artykuł stanowi wersję publikacyjną trzech referatów o tzw. zrównoważonym rozwoju. Pierwszy referat był wygłoszony w grudniu 2013 r. w Białowieży na konferencji organizowanej wspólnie przez Urząd Statystyczny w Białymstoku oraz Uniwersytet w Białymstoku. Drugi referat był wygłoszony w 2014 r. na konferencji zorganizowanej przez Katedrę Statystki Uniwersytetu Ekonomicznego we Wrocławiu. Trzeci referat został wygłoszony w ramach akcji edukacyjnej prowadzonej przez PTS Oddział we Wrocławiu, również w 2014 r. Celem wszystkich referatów było wyjaśnienie znaczenia angielskiego terminu sustainable development, dokonanie przeglądu podstawowej literatury i jej krytyczne omówienie. Artykuł niniejszy ma taki sam cel. Wydawać by się mogło dziwne, że po upływie blisko 20 lat od kiedy wyrażenie „zrównoważony rozwój" pojawiło się w literaturze polskiej, zarówno w naukowej, jak i publicystycznej, propagandowej, politycznej itp. odważyłem się wystąpić z twierdzeniem, że pojęcie to wymaga wyjaśnienia. Niestety jest to prawda, którą poświadczają fragmenty publikacji przytoczone w ostatnim paragrafie tego artykułu. W spisie literatury wymienione są też prace godne polecenia jako lektura obowiązkowa, nie omawiam ich ze względu na ograniczone ramy artykułu.
\end{abstract}

Słowa kluczowe: trwały rozwój, zachowanie planety, krytyka słownictwa, polskie publikacje.

\section{Sustainability, czyli Пусть всегда будет солнце}

Prawdopodobnie nikt nie jest w stanie, przynajmniej na obecnym etapie, wyjaśnić przyczyny fenomenu niezwykłej popularności wyrażenia „zrównoważony rozwój” w piśmiennictwie polskim. Cały naród, niemal jednym głosem, wyraża zatroskanie zrównoważonym rozwojem, na uczelniach powstają Centra Doskonałości zrównoważonego rozwoju, organizowane są Kongresy Obywatelskie, nie wymieniając „zwykłych” seminariów, konferencji czy nawet Festiwali zrównoważonego rozwoju. Nie ma znaczenia, że nie wiadomo, co z czym ma być równoważone, kto ma równoważyć, ani też czego rozwój ma dotyczyć. Ważne żeby nauczenie było zrównoważone, żeby firmy były zrównoważone, żeby konsumpcja była zrównoważona, żeby człowiek był zrównoważony. Korporacje, które jeszcze do niedawna żonglowa- 
ły użytecznym dla nich określeniem ,społeczna odpowiedzialność korporacji”, teraz uzupełniają je „zrównoważeniem”. „Odpowiedzialność" jest terminem klarownym, można ją egzekwować, a przynajmniej wiadomo za co jest się odpowiedzialnym, i przed kim. „Zrówoważoność" nie wiadomo co oznacza, ale ponieważ jest to termin w jakimś sensie ważny, lubiany i popularny, to bezpieczniej jest deklarować zrównoważoność niż odpowiedzialność. Zamiast oznajmiać, że korporacja jest odpowiedzialna, lepiej reklamować to, że korporacja jest zrównoważona, i jej biznes jest zrównoważony. Pisarstwo na temat zrównoważenia rozwija się, ale jak dotychczas, nie jest ono wcale zrównoważone. Tak, zupełnie na zdrowy rozsądek, pojęcie rozwoju musi zawierać element czasu. Jeżeli coś w chwili obecnej kształtuje się na określonym poziomie, a w kolejnych momentach czasowych to coś kształtuje się na takim samym lub wyższym poziomie, to mówi się o jego rozwoju. Jeżeli wyrażenie „zrównoważony rozwój” nie miałoby być oksymoronem, to trzeba by pewnie wskazać coś innego wykazującego regres, z którym progres by się równoważył.

W Przedmowie do polskiego wydania książki H. Rogalla [2010, s. 19] Poskrobko pisze:

„Pojawiają się więc różne nurty ekonomii heterodoksyjnej. Jednym z nich jest ekonomia zrównoważonego rozwoju. Podstawą tej nauki jest idea sustainable development różnie rozumiana przez polskich autorów - jako ekorozwój, rozwój zrównoważony, trwały, suspensywny, rozwój trwały i zrównoważony. Komitet Prognoz Polskiej Akademii Nauk podjął nawet uchwałę, że w wydawanym pod jego auspicjami czasopiśmie naukowym «Przyszłość» można używać tylko pojęcia «rozwój trwały». Dziwi stanowisko tak szacownego gremium".

Dziwne jest raczej to zdziwienie znanego eksperta $\mathrm{w}$ dziedzinie ekonomiki ochrony środowiska. „Trwanie” albowiem jest najbliższym odpowiednikiem angielskiego rzeczownika sustainability. Wyrażenie sustainable development oznacza „rozwój trwający, rozwój utrzymujący się” lub tak jak proponuje PAN „rozwój trwały”. Ani niemiecki wyraz, ani angielski nie mają żadnego związku z ważeniem czy równoważeniem czegokolwiek. Popularna niegdyś piosenka jest najlepszym poetyckim określeniem znaczenia terminu sustainability. Niechaj zawsze świeci słońce, niechaj zawsze rosną drzewa, niechaj zawsze wystarczy każdemu chleba pachnącego chlebem. Niechaj zawsze będzie Matka Ziemia, ta najpiękniejsza planeta wszechświata, błękitna perła kosmosu, nasza oaza kosmiczna, na wszystkich jej kontynentach i oceanach złączeni jak flora i fauna stanowimy jeden ród na wspólnej 
Ziemi. Jesteśmy istotami ludzkimi, a Ziemia jest naszym domem. Taka jest treść Hymnu do Matki Ziemi, ustanowionego w 1970 r. i każdego roku, w dniu Święta Ziemi tzn. 22 kwietnia, śpiewanego w bliSTATYSTYCZNY sko 200 krajach świata. Hymn ten nie został, jak na razie, przetłumaczony na język polski. Zakończmy więc ten paragraf zwrotką thumaczenia czeskiego, także dobrze oddającą sens sustainability: jako zviŕata a květiny, jsme jeden lidský rod na společné Zemi.

\section{Przyczyny zainteresowania i zamieszania}

Głównym bodźcem zainteresowania trwałością ekosystemu jest uświadomienie sobie, że „obietnica nieograniczonego postępu obietnica panowania nad przyrodą, materialnego dostatku, największego szczęścia dla jak największej liczby osób i nieskrępowanej wolności osobistej" nie tylko okazała się złudzeniem, lecz także samo istnienie ludzkiej rasy jest zagrożone (por. [Fromm 1999]). Podobną opinię znajdujemy też w Raporcie Brundlnady: „lata sześćdziesiąte były okresem optymizmu i postępu, były czasem nadziei na bardziej sprawiedliwy nowy świat i na postępowe idee międzynarodowe... Lata siedemdziesiąte oznaczały popadnięcie w nastroje wstecznictwa i izolacji” (por. [Nasza... 1991, s. 11]). W książce Ludzkość i Matka Ziemia (Mankind and Mother Earth) sławny historyk A. Toynbee zauważa, że człowiek, dziecko Matki Ziemi, nie przeżyje, jeśli popełni zbrodnię matkobójstwa. Nie mamy innego wyboru: albo ratujemy ją i siebie, albo dobijamy ją i giniemy. Po raz pierwszy w historii samo istnienie ludzkiej rasy zależy od radykalnej odmiany ludzkiego serca [Fromm, 1999, s. 47].

Nikt nie ma wątpliwości, że cała nasza (ludzka) egzystencja zależy od tego: co, ile i jakiej jakości dostajemy od Matki Ziemi. Dostajemy, a często rabujemy, bardzo dużo, w zamian nie obchodzimy się z nią najlepiej, nie okazujemy należnej jej miłości, kalamy ją swoimi odpadami i truciznami. Najważniejsze jest to, że eksploatujemy ją ponad miarę. $\mathrm{Z}$ drugiej zaś strony, nie mamy umiaru $\mathrm{w}$ maltretowaniu jej swoimi odpadami i truciznami (por. rys. 1).

W latach 2001-2005 dokonano ,inwentaryzacji” zasobów ekosystemu. Wyniki okazały dość smutne. Degradacja środowiska jest przerażająca. Do pomiaru stanu zasobów obszarów bioproduktywnych zastosowano jednostkę hektara przeliczeniowego, zwanego hektarem globalnym (gha). Na początku roku 2000 oszacowano, że ludzkość na całym świecie ma do dyspozycji 11,5 mld gha, czyli przydział na jedną osobę wynosi 1,8 gha. W skali całego świata, zużywamy jednak 


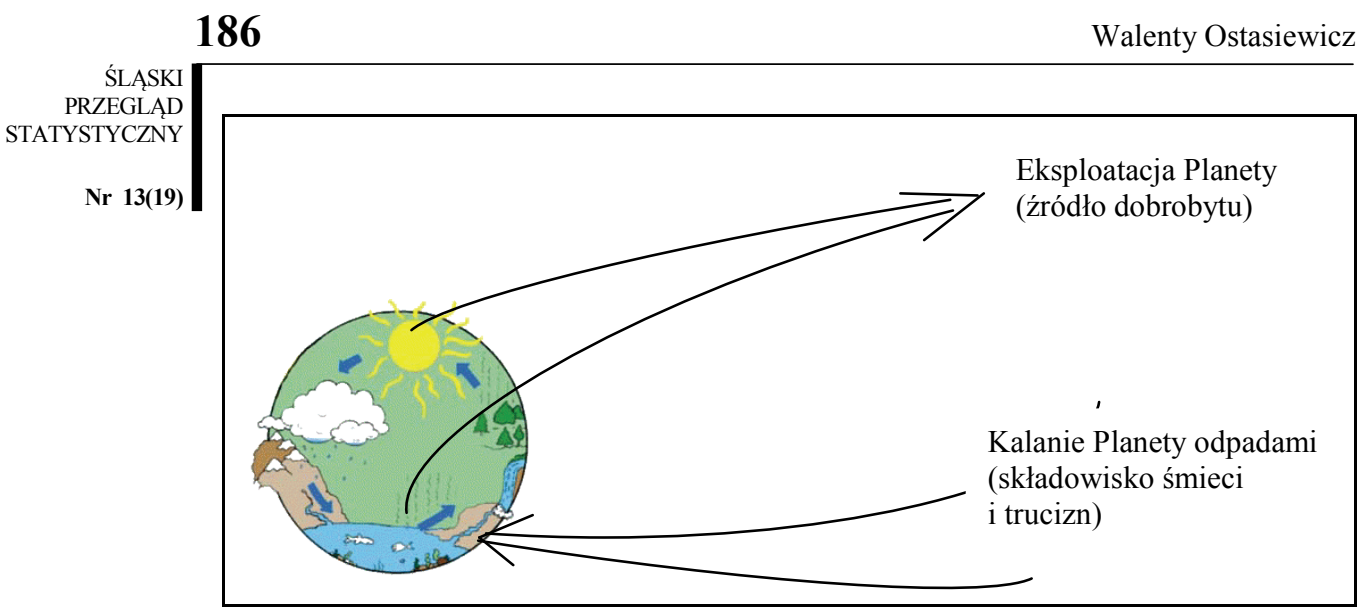

Rys. 1. Korzystanie z usług ekosystemu i zanieczyszczanie

Źródło: opracowanie własne.

dużo więcej. Na prawie 200 krajów świata objętych badaniem okazało się, że niektóre kraje żyją kosztem innych. W języku naukowym mówi się, że mają one dług ekologiczny (lepsze określenie: ekosystemowy, bo ekologia to nauka, a dług zaciągają $\mathrm{w}$ realnych wielkościach ekosystemu). W języku mniej wykwintnym określa się to mianem imperializmu lub złodziejstwa, bo długu tego raczej nigdy nie zwrócą, tak jak kolonizatorzy Ameryki nigdy nie zwrócili długu za tony zrabowanego złota i srebra. Mało tego, dzisiejsi ich potomkowie, po Zjednoczonych Emiratach Arabskich, są największym dłużnikiem ekosystemowym. Zamiast przydziału 1,8 gha, USA zużywa aż 9,6 gha. Drugiej Ameryki świat nie byłby w stanie utrzymać [Rifkin, Howard 2008]. W swoim życiu każdy Amerykanin zużywa przeciętnie około 700 ton zasobów naturalnych. Obliczono, że Amerykanin należący do klasy średniej prowadzi taki styl życia, który jest równoważny pracy wytwarzanej przez 200 niewolników. Przeciętny Amerykanin zjada 800 kg zbóż rocznie (większość pośrednio jako wołowinę), przeciętny mieszkaniec krajów biednych zjada zaś 200 kg zbóż. Typowy Amerykanin zużywa 200 razy więcej paliw kopalnych niż mieszkaniec Indii i 300 razy więcej niż obywatel Mozambiku. Średnio w całym świecie na zbrojenia wydaje się prawie 1 milion dolarów w każdej minucie. Ameryka przoduje, i nadaje ton w przetapianiu lemieszy przyszłych pokoleń w dzisiejsze miecze lub głowice do rakiet [Rifkin, Howard 2008].

Oprócz tego, że średnio w całym świecie przekraczamy zdolności bioprodukcyjne planety, to do tego obchodzimy się bardzo rozrzutnie z dobrodziejstwem natury. Zauważmy przede wszystkim, że gospo- 
darka jest to system, w którym przekształca się materię i energię do postaci użytecznej ludziom. Materia pobierana jest ze środowiska, energia zaś pobierana jest ze środowiska i ze słońca, po przekształceSTATYSTYCZNY niu wydalana jest w postaci energii i materii do środowiska (w postaci użytecznych dóbr i odpadów). Pamiętać trzeba też o tym, że materii stworzyć nie możemy, nie możemy jej też zniszczyć, możemy tylko ją przetwarzać, albo w użyteczną, albo w bezużyteczną. Energię natomiast, możemy tylko marnować. Jeśli uwzględnimy te fakty, to możemy zrozumieć, że powinniśmy tak gospodarować, aby jak najmniej tracić (marnować) energii, i jak najmniej przekształcać materię w bezużyteczne odpady i zaśmiecać środowisko. Zauważmy ponadto, że do uzyskania energii trzeba zużyć także energię. W zależności od źródła pochodzenia energii, koszt jej pozyskania jest różny. Załóżmy, że nakłady na uzyskanie energii mierzone będą za pomocą BTU (brytyjska jednostka energii) oraz uzyskaną energię mierzymy w tych samych jednostkach. Oto jak kształtuje się koszt pozyskiwania energii z kilku źródeł: uzyskanie 1 BTU w postaci ropy naftowej kosztuje 1/50 BTU, w postaci węgla kamiennego $1 / 17$, zaś w postaci oleju łupkowego aż 1/6 BTU. Oznacza to, że zużywając 1 BTU, uzyskujemy 50 BTU w postaci ropy. Uzyskiwanie energii w postaci gazu czy oleju łupkowego nie tylko, że jest kosztowne energetycznie, lecz także jest związane $\mathrm{z}$ degradacją środowiska w postaci oparów toksycznych i ze zużyciem wody [Rifkin 2008]. Energię zawartą w produktach żywnościowych mierzy się jednostkami kalorycznymi. Weźmy dla przykładu puszkę kukurydzy, która zawiera 270 kalorii. Na jej wyprodukowanie trzeba zużyć aż 2790 kalorii. Poza tak ogromnym zużyciem energii dochodzą jeszcze opady zanieczyszczające środowisko. Oszacowano, że wytworzenie jednej jednostki dobra materialnego powoduje wytworzenie aż 70 jednostek odpadów [Heines 2013]. Na przykład tylko w jednym roku 1987 Amerykanie wyrzucili ponad $200 \mathrm{mln}$ ton odpadów, w tym $80 \mathrm{mln}$ ton papieru. O prawdziwym zanieczyszczeniu środowiska świadczą odpady radioaktywne, o nich to można $\mathrm{z}$ całą pewnością stwierdzić, że są sustainable, gdyż trwają praktycznie wiecznie. Radioaktywności zlikwidować nie można. A zostawiamy jej przyszłym pokoleniom coraz więcej. Trzeba też pamiętać, że nawet jedna cząsteczka radioaktywna, jeśli się dostanie do komórki, może spowodować raka lub mutacje genetyczne. Proces ten może następować podstępnie i dać objawy nawet po nawet po 20 latach.

Na całym świecie zgromadzono ponad sześć miliardów ton pozostałości po przeróbce rud uranu. W latach 1959-1962 Szwecja zatopi- 
ła w Bałtyku około 120 ton odpadów radioaktywnych [Bohdanowicz 1998]. W południowo-zachodnich stanach USA zgromadzono już 100 mln ton odpadów. W Colorado użyto takich odpadów do budowy szkół i domów, lekarze zauważyli wzrost liczby wad wrodzonych u dzieci, których rodzice mieszkali lub pracowali w takich budynkach [Rifkin, Howard 2008].

W wyniku odwrócenia kierunku przepływu dwóch rzek Syr-darii i Amu-darii, poziom morza Aralskiego obniżył się o $14 \mathrm{~m}$, zginęło wszelkie życie w zasolonej wodzie. W Kanadzie jest 14000 zupełnie martwych jezior. Podobnie sytuacja wygląda w USA, gdzie 50000 jezior jest zatrutych rtęcią. Obecne pokolenie z takiej wody nie korzysta, a przyszłe? W Morzu Arktycznym zostawiliśmy przyszłym pokoleniom 19 reaktorów z okrętów wojennych. Kiedyś rdza zrobi swoje i wody tego morza na zawsze będą napromieniowane, ale przecież nas już wtedy nie będzie, après moi le déluge.

\section{Mania wzrostu towarzyszy ludziom od niedawna}

J. Ruskin już w 1862 r. kreśląc karykaturalny obraz ekonomii, którą T. Carlyle nazwał smutną lub żałosną nauką (ang. dismal science), wprowadził antonimy podstawowych pojęć tej nauki. Twierdził, że nie ma bogactwa, jest zaś życie, czyli miłość, radość, szacunek. To on prawdopodobnie po raz pierwszy wyraźnie zwrócił uwagę na potrzebę rozpatrywania obu biegunów, tego pozytywnego i negatywnego. Zadziwiający jest fakt, że ludzkość tak była, i jest nadal, przejęta dążeniem do bogactwa, przyjemności i rozkoszy, że nawet nie wytworzyła odpowiedniego słownictwa. Jako antonim dla angielskiego wyrazu wealth, Ruskin wymyślił wyraz illth. Stąd też mamy obecnie welfare oraz illfare. $\mathrm{W}$ języku polskim antonimem bogactwa mogło by być złostwo, zaś dobrobytu - złobyt. J.K. Galbraith opublikował w 1958 r. książkę pt. The Afluent Society (Społeczeństwo zamożności), w której wskazał na koszty związane ze wzrostem gospodarczym. Wzrost gospodarczy oznacza wzrost zamożności, ale tylko nielicznych grup, oraz wzrost ubóstwa masowego. Wraz ze wzrostem gospodarczym rośnie przepaść między garstką bogaczy a masami biedoty. Jego książka była jednak zignorowana przez ekonomistów. Traktowano go bowiem bardziej jako komentatora niż ekonomistę. W 1965 r. została wydana książka The great transformation, w której jej autor K. Polanyi wykazał główne przyczyny degradacji społeczeństwa. W $1966 \mathrm{r}$. $\mathrm{K}$. Boulding opublikowal słynny artykuł The economics of the Coming 
Spaceship Earth, w której porównywał ziemię do statku kosmicznego,

z którego nie można śmieci przez okno wyrzucić i nie można dostać z zewnątrz środków do życia.

Burzę, zamęt i niezadowolenie wśród ekonomistów wywołał E.J. Mishan. Po pierwsze dlatego, że był znanym i szanowanym w świecie ekonomistą. Po drugie, pracę doktorską przygotował on pod kierunkiem najbardziej żarliwego i znanego w świecie propagatora nieograniczonego wzrostu gospodarczego, M. Friedmana. Jednak już po dwóch latach opuścił Uniwersytet w Chicago i zajął się analizą społecznych kosztów wzrostu. W 1965 r. przygotował książkę na ten temat, żaden $\mathrm{z}$ wydawców nie chciał jej jednak opublikować. Po dwóch latach szczęście mu dopisało, książka pod tytułem The Cost of Economic Growth, została opublikowana w 1967 r. W książce tej przedstawione zostały koszty, jakie ponosi społeczeństwo w związku z osiąganiem coraz większego wzrostu gospodarczego. E. Mishan wykazał, że wytwarzane złostwo, jako suma wszelkich nie-dóbr przewyższa wytwarzane dobra. Do nie-dóbr zaliczył on nie tylko zanieczyszczenie powietrza, hałas w miastach, lecz także takie negatywne i patologiczne zjawiska społeczne, jak dezintegracja społeczna, atomizacja, rozwody, samobójstwa, rozboje, dewiacje seksualne itp.

W kwietniu 1968 r. grupa 30 osób z 10 krajów spotkała się w rzymskiej Akademii dei Lincei, inaugurując powstanie jednej z najważniejszych organizacji pozarządowych, której celem było przeciwdziałanie trudnej sytuacji, w jakiej znalazła się ludzkość w wyniku prowadzenia rabunkowej gospodarki społecznie niesprawiedliwej. Inicjatorem tego spotkania był przemysłowiec włoski Aurelio Peccei (por. [Ciążela 2007]). Powstała organizacja nosi nazwę Klubu Rzymskiego. Z inicjatywy tego Klubu zrealizowany został projekt The Predicament of Mankind przez zespół międzynarodowy pod kierownictwem D. Meadowsa. Raport z realizacji tego projektu opublikowano w 1972 r. w postaci książki pt. The limits to growth, pod redakcją zespołu: D.H. Meadows, D.L. Meadows, J. Randers, W.W. Behrens III. W książce Granice wzrostu (wydanej przez PWE w 1973 r.) wykazano, że nieograniczony wzrost nie jest możliwy ze względu na ograniczoność zasobów naturalnych. Rok później, czyli w 1973 r, została wydana książka Schumachera pt. Small is beautiful, mimo iż ze względu na intelektualny ładunek znacznie przewyższa Granice wzrostu, to jednak wciąż jest zaledwie cytowana. Oprócz ograniczeń naturalnych (przyrodniczych) zidentyfikowano obecnie szereg innych ograniczeń określających granice nieskończonego wzrostu gospodar- 
czego. W szczególności są to ograniczenia społeczne, dobrobytowe oraz entropowe. Granice społeczne wyznaczają rosnące koszty społeczne wzrostu gospodarczego. Jeśli one znacznie przewyższą korzyści ze wzrostu, to wzrost gospodarczy zacznie przynosić więcej szkody niż pożytku. Ograniczenia wzrostu dobrobytu (przy tym mniejszości) powodowane są produkcją tzw. dóbr służących do wykazania swego stanu czy pozycji społecznej. Do dóbr tego typu należą np. zegarki luksusowe. Natomiast granice entropowe (fizyczne) określone są przez dwa podstawowe prawa termodynamiki. Pierwsze prawo oznacza, że materii i energii zwiększyć nie można, nie można ich bowiem stworzyć. Drugie prawo oznacza to, że energię można tylko marnować. Zapasy materii i energii są skończone. Jeśli nawet będzie to w bardzo odległej przyszłości, to jednak kiedyś się one wyczerpią.

\section{Globalny program zmian}

„Globalny program zmian - tak Zgromadzenie Ogólne ONZ sformułowało oczekiwania wobec Światowej Komisji do spraw Środowiska i Rozwoju", takimi też słowy rozpoczyna się słynny Raport opublikowany przez tę Komisję, którą kierowała Gro Harlem Brundtland (z powodu wielu niedorzeczności pojawiających w literaturze, wyjaśnijmy: Gro jest to imię żeńskie, Harlem nazwisko panieńskie, Brundtland - nazwisko męża tej słynnej kobiety). Pojęcie „sustainable development" w tym Raporcie zostało sformułowane następująco: Sustainable development is development that meets the needs of the present without compromising the ability of future generations to meet their own needs.

W polskim, solidnym przekładzie dokonanym przez U. Grzelońską i E. Kolanowską mamy następującą wersję: „Stabilny rozwój, oznacza rozwój, który zaspokaja potrzeby obecne, nie pozbawiając przyszłych pokoleń możliwości zaspokojenia ich potrzeb" [Nasza... 1991, s. 67].

W nieco innej wersji, zamiast stabilny rozwój, użyto określenia stały rozwój. Ten wariant definicji jest następujący: „Ludzkość jest w stanie sprawić, aby rozwój był stały i zapewniał zaspokojenie obecnych potrzeb bez uszczerbku dla możliwości zaspokajania potrzeb przyszłych pokoleń" [Nasza... 1991, s. 27].

Nie są to jedyne definicje, w Raporcie jest ich sześć wariantów. Autorom Raportu zależało bowiem na przekazaniu bardziej idei niż ścisłych zaleceń, bardziej na przekazaniu ducha niż litery. Raport 
Komisji kierowanej przez Brundtlandę, to nie dokument biurokratyczny, lecz lektura dla tych, którzy mają rozum i serce, i wiedzą, że duch ożywia, a litera zabija. Autorzy Raportu tak to sami określają: „Przede STATYSTYCZNY wszystkim nasze przesłanie jest adresowane bezpośrednio do ludzi, których dobro jest ostatecznym celem każdej polityki dotyczącej środowiska i rozwoju. Komisja zwraca się zwłaszcza do ludzi młodych. Szczególna rola przypada nauczycielom, którzy młodym przedstawią ten raport" [Nasza... 1991, s. 15].

Nie wiadomo, kiedy pojawiło się polskie wyrażenie ,zrównoważony rozwój", jest ono najbardziej nieodpowiednim thumaczeniem angielskiego określenia sustainable development. Nieodpowiednim, bo nie oddającym ani sensu, ani istoty, czy ducha, jaki jest zawarty w angielskim słowie sustainability. Aby wyjaśnić istotę znaczenia tego terminu, warto sięgnąc do korzeni, z których ono wyrastało. Na początku XIX w. ubiegłego stulecia ludzkość zauważyła, że nierozsądne gospodarowanie zasobami leśnymi może doprowadzić do ich wyniszczenia. Rozsądne gospodarowanie polega na tym, aby zachować trwałość zalesienia. Oznacza to, że wycinać można tyle, ile się wcześnie zasadziło. Lasy są bardzo ważne, więc trzeba z nich tak korzystać, aby one zawsze trwały, aby trwale służyły ludzkim potrzebom. Wielokrotnie powtarzane tu słowo ,trwale”, jest niezwykle ważne, jego niemieckim odpowiednikiem jest słowo Nachhaltigkeit. Słowa tego po raz pierwszy użył Hans (Hannß) Carl von Carlowitz w wydanej w 1713 r. książce o bardzo długim tytułe, którego początek jest taki: Sylvicultura oeconomica, oder haußwirthliche Nachricht und Naturmäßige Anweisung zur wilden Baum-Zucht. W książce tej opisywał sposoby gospodarowania gwarantujące utrzymywanie zalesienia na stałym poziomie. Gospodarkę taką, także współcześnie, w języku niemieckim określa się mianem nachhaltige Wirtschaft. Słowo Nachhaltigkeit bardzo dobrze oddaje istotę rzeczy, pochodzi od słowa halten, czyli utrzymywać, dbać, troszczyć się. Angielskim odpowiednikiem halten jest słowo czasownik to sustain, oznacza ono utrzymywać, kontynuować, podtrzymywać. Jeśli mówimy o sustainability, to trzeba sobie uświadomić, że ten rzeczownik pochodzi od czasownika to sustain, czyli utrzymać. Jeśli jednak zaczniemy mówić o utrzymaniu, to musimy zdecydować o tym, co ma być utrzymane, i przez co lub przez kogo ma być utrzymywane.

Przyjmijmy, że tym co chcemy utrzymać, jest gospodarka, chcemy żeby ona trwała i żeby się rozwijała, co nie oznacza dążenia do jej wzrostu. Wzrost a rozwój są to różne rzeczy, poza tym pamiętajmy 
jednak, że tym, co ją utrzymuje i od czego ona zależy, jest ekosystem. Jeśli nie będzie ekosystemu, nie będzie też gospodarki. Ekosystem musi też być zdrowy i dostatecznie silny, aby gospodarkę utrzymać.

\section{Istota i sens trwającego rozwoju}

„Środowisko zaś jest przecież tym domem, w którym wszyscy żyjemy, a rozwój jest tym, w czym wszyscy uczestniczymy, starając się poprawić nasze miejsce w tym domu". Tak pisze G. Harlem Brundtland w słowie wstępnym do zredagowanego przez siebie Raportu. Strukturę naszego gospodarowania w tym domu można więc przedstawić tak jak zostało to pokazane na rys. 2 .

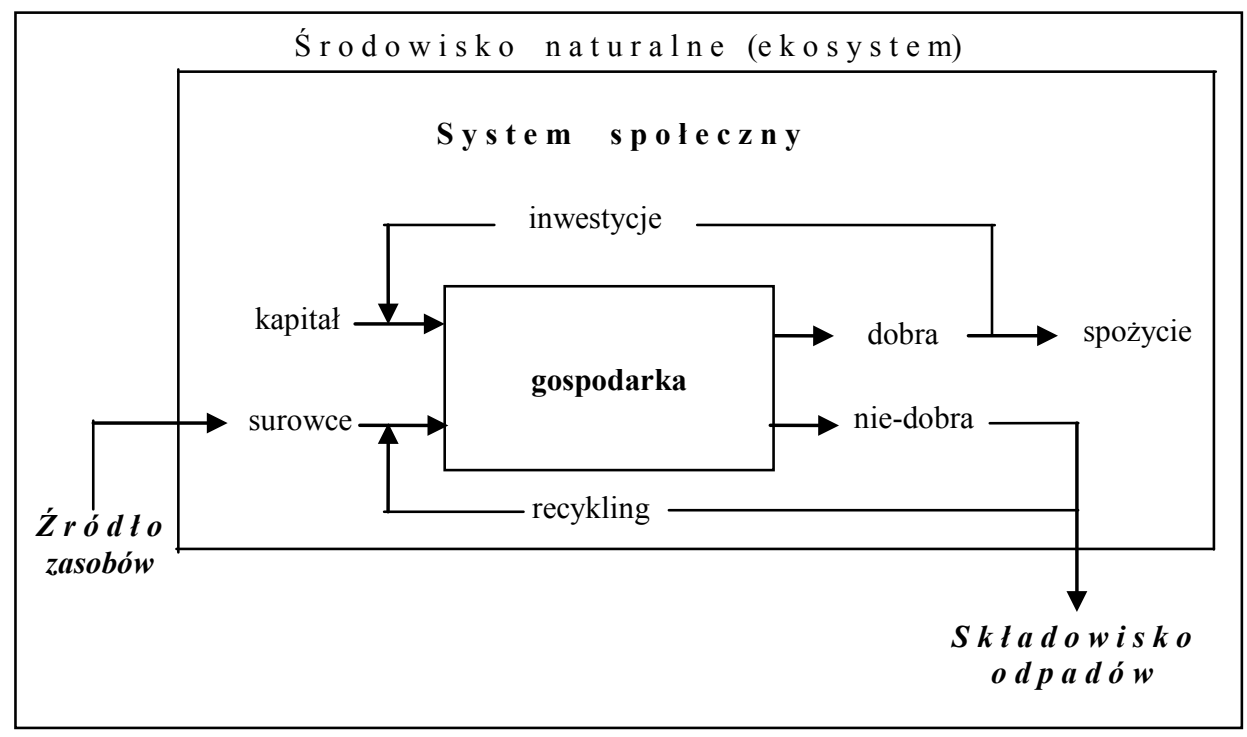

Rys. 2. Schemat trzech podporządkowanych sobie systemów

Źródło: opracowanie własne.

$\mathrm{Z}$ powyższego schematu widzimy, że nauka o gospodarowaniu (ekonomia) nie może być rozwijana autonomicznie, w oderwaniu od innych dziedzin ludzkiej wiedzy, głównie takich jak ekologia i socjologia. W każdej z tych trzech podstawowych dziedzin formułowane są własne, specyficzne cele. Głównym celem ekonomistów jest wzrost gospodarczy, oceniany w kategoriach wielkości produkcji i efektywności. Przedstawiciele nauk zajmujących się głównie społeczeństwem, jako główny cel badań traktują sprawiedliwość społeczną, zaś ekolo- 
dzy - trwałość środowiska naturalnego. Wszystkie cele są powiązane ze sobą, ale jednocześnie nie są ze sobą zgodne. Chcąc rozwijać naukę o trwałym, czyli utrzymującym się stale rozwoju musimy zdecydować STATYSTYCZNY o tym, czego rozwój ma dotyczyć, czyli co powinno być utrzymywane na nie obniżającym się poziomie. Utrzymywać zwykle chcemy to, co jest cenne, co jest dla nas wartościowe. Dla jednych jest to wzrost bogactwa, dla innych jest to rozwój duchowy. Nieco konkretniej, jedni chcą zachować (utrzymać) środowisko naturalne, inni wolą zachować kapitał, a jeszcze inni - użyteczność, czy nawet szczęśliwość. Wybór konkretnego celu zależy od przyjętego systemu etycznego, a także od systemu ideologicznego. Czynione obecnie wysiłki w kierunku rozwoju nauki o trwałym rozwoju można scharakteryzować, umieszczając je na osi ideologicznej: lewicowość (Zieloni, progresywiści, radykaliści) - prawicowość (konserwatyści, fundamentaliści). Najbardziej radykalni optują za sprawiedliwością społeczną i zachowaniem środowiska naturalnego. Należą do nich przedstawiciele ekosocjalizmu, socjoekonomii, ekonomii feministycznej, ekologii głębokiej i inni. Jedyną cechą bezsprzeczną łączącą te kierunki jest absolutne odrzucenie kapitalizmu jako modelu gospodarowania. Na przeciwległym, bardzo odległym, biegunie lokują się zwolennicy kapitalizmu. Nie stanowią także grupy jednorodnej. Można wśród nich wyodrębnić przynajmniej trzy obozy. Najbardziej zwarty, z dużym bojowym doświadczeniem, jest obóz fundamentalistów, czyli zwolenników kapitalizmu koropracyjnego. Świątynią dla większości z nich jest Bank Światowy. Do drugiego obozu należą zwolennicy wyzieleniania kapitalizmu, ich wysiłki skierowane są więc na stworzenie kapitalizmu z ludzką twarzą. Trzeci obóz stanowią apostaci, których zdecydowanym liderem jest Herman Daly [2007].

Ze względu na ograniczoność objętości artykułu niżej podane są dwa dość typowe podejścia ekonomiczne. Pierwsze z nich polega na zastąpieniu zupełnie nieprzydatnego wskaźnika wzrostu gospodarczego, jakim jest PKB, wskaźnikiem, który nie ma jeszcze utartej nazwy, ale stosowane są takie wyrażenia, jak: comprehensive wealth, inclusive health, genuine wealth, itp. Nazwijmy go Bogactwem Kraju Globalnym (BKG), nazwa taka dobrze oddaje sens i koresponduje ze skrótem PKB. Drugi przykład dotyczy słynnego kryterium sprawiedliwości międzypokoleniowej, które w 1996 r. zaproponowała G. Chichilinsky.

Załóżmy, że szczęśliwość społeczna (ang. social felicity) w momencie $s$ oznaczona będzie symbolem $U((\underline{C}(s), \underline{K}(t))$, przy czym symbol 
$\underline{C}(s)$ oznacza wektor konsumpcji, zaś $\underline{K}(t)=\left(K_{1}(t), K_{2}(t), \ldots, K_{n}(t)\right)$ oznacza wektor kapitału, $K_{i}(t)$ - oznacza zasób $i$-tego kapitału w momencie $t$. Zasób kapitału $\mathrm{w}$ momencie $t$ jest to wielkość $V(t)=$ $V(\underline{K}(t), t)$ zależna od wektora kapitału określony jest za pomocą wzoru:

$$
V(t)=\int_{t}^{\infty}\left[U\left(\underline{C}(s), \underline{K}(t) e^{-\delta(s-t)}\right] d s, \delta \geq 0,\right.
$$

gdzie $\delta \geq 0$ oznacza stopę dyskontową szczęśliwości.

Przyjmuje się definicję, że w momencie $t$ rozwój ekonomiczny jest utrzymany (ang. is sustained), uważa się jeśli

$$
\frac{d V(t)}{d t} \geq 0
$$

Zwróćmy tu wyraźnie uwagę na to, że rozwój nie jest równoważony ani zrównoważony, lecz jest sustained. Powyższe kryterium trwałości rozwoju ekonomicznego można wyrazić w postaci jawnej:

$$
\frac{d V(t)}{d t}=\frac{\partial V}{\partial t}+\sum_{i} \frac{\partial V(t)}{\partial K_{i}(t)} \frac{d K_{i}(t)}{d t}
$$

Wprowadźmy oznaczenia

$$
p_{i}(t)=\frac{\partial V(t)}{\partial K_{i}(t)} r_{i}(t)=\frac{\partial V(t)}{\partial t} .
$$

Wielkość $p_{i}(t)$ interpretujemy jako chwilową cenę dualną (księgową) $i$-tego kapitału, zaś $r_{i}(t)$ interpretuje się jako cenę dualną czasu, czas bowiem, jest traktowany jako szczególny rodzaj kapitału. Bogactwo kraju globalne (BKG) w momencie $t$ definiuje się jako wartość w cenach dualnych wszystkich rodzajów kapitału:

$$
W(t)=r(t) t+\sum_{i}\left[p_{i} K_{i}(t)\right]
$$

Zobaczmy dla przykładu, na jakim poziomie kształtowało się bogactwo globalne USA w roku $2000 \mathrm{w}$ miliardach dolarów w przeliczeniu na głowę mieszkańca [Arrow i in. 2010]:

Kapitał naturalny $=5694,73$, kapitał ludzki -60 086, 93, kapitał reprodukowany - 13 430,66, czyli ogółem kapitał łączny (globalny) wynosił 79212329 mld dolarów.

Porównajmy jeszcze dynamikę PKB oraz BKG w krajach rozwijających się. Porównajmy mianowicie roczny wzrost PKB na głowę 
mieszkańca i BKG także na głowę mieszkańca w latach 1970-2000.

$\mathrm{W}$ Indiach wzrost ten wynosił odpowiednio 3\% $\mathrm{i}-0,45 \%$, w Pakista-

nie $2,2 \%$ i $-1,42 \%$, zaś w Chinach $7,8 \%$ i $4,47 \%$ (por. [Dasgupta 2008]).

W celu rozpatrzenia kryterium sprawiedliwości międzypokoleniowej przyjmijmy, że $x_{0}$ oznacza stan zasobów naturalnych w początkowym momencie, $x_{t}$ stan zasobu w momencie $t$, zaś $c_{t}$ zużycie (wydobycie, konsumpcja) surowców w tym samym momencie. Zadowolenie (satysfakcja) każdego pokolenia charakteryzowana jest za pomocą funkcji użyteczności $U\left(c_{t}, x_{t}\right), t=0,1,2, \ldots$ Zdyskontowana na moment zerowy użyteczność wszystkich pokoleń określa się według wzoru:

$$
\sum_{t=0}^{\infty} \beta^{t} U\left(c_{t}, x_{t}\right)
$$

Natomiast użyteczność pokolenia nieskończenie odległego od pokolenia obecnego określa następująca granica: $\lim _{t \rightarrow \infty} U\left(c_{t}, x_{t}\right)$. Kryterium służące do oceny sprawiedliwości międzypokoleniowej definiuje się w postaci kombinacji wypukłej dwóch wyżej zdefiniowanych wielkości [Figuieres, Tidbal 2012]:

$$
J=\theta \sum_{t=0}^{\infty} \beta^{t} U\left(c_{t}, x_{t}\right)+(1-\theta) \lim _{t \rightarrow \infty} U\left(c_{t}, x_{t}\right), \theta \epsilon(0,1] .
$$

Zauważmy, że jeśli $\theta=1$, to mamy do czynienia $\mathrm{z}$ tradycyjnym podejściem, jakie jest stosowane w ekonomii neoklasycznej. Niestety podejście takie, czyli stosowanie zdyskontowanej użyteczności do oceny polityki, mimo iż jest stosowane dość powszechnie w ekonomii środowiska naturalnego, ma zbyt dużo wad, żeby można je było stosować nawet jako mocno uproszczony sposób oceny polityki dotyczącej wydobycia surowców i konsumpcji. Jeżeli zaś parametr $\theta$ jest bliski zeru, to dużą wagę przypisuje się pokoleniom bardzo odległym.

W przypadku zagadnień dotyczących społeczeństwa zarówno tradycyjnie, jak i bardziej nowocześnie, tzn. zgodnie z duchem Raportu Brundtlandy, wysiłki skierowane są na opracowywanie odpowiednich wskaźników, charakteryzujących sprawiedliwość społeczną, wykluczenie, ubóstwo itp. To samo można powiedzieć o „sektorze” środowiskowym. Niezależnie od wielu deklaracji, żadnej nauki o trwałym i zrównoważonym rozwoju jeszcze nie opracowano. Najbardziej solidne zręby położono pod ekonomię ekologiczną. Idealnym rozwiązaniem byłoby pogodzenie trzech celów. Takie idealne rozwiązanie przedstawić można $\mathrm{w}$ postaci obszaru wewnątrz trójkąta, którego wierzchołki odpowiadają trzem ekstremalnym punkom widzenia (por. rys. 2). 


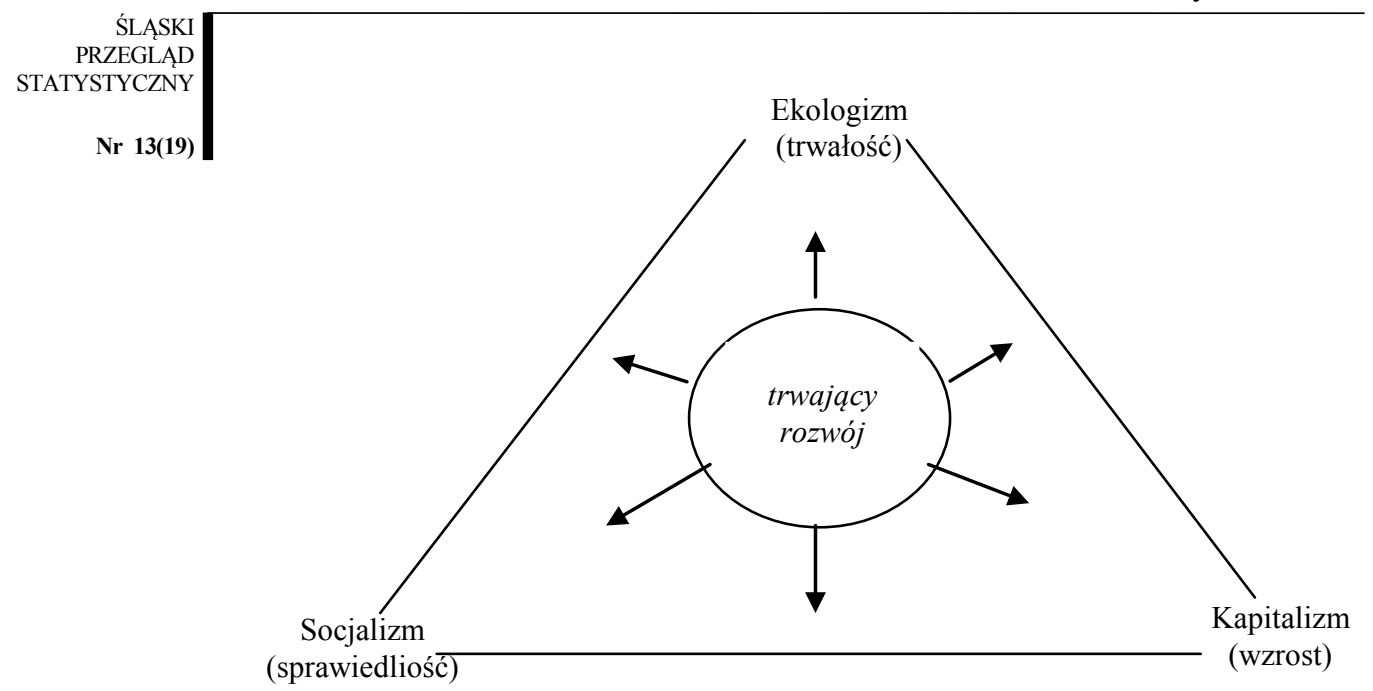

Rys. 3. Miejsce trwałego rozwoju w przestrzeni ideologiczno-politycznej wyznaczonej przez ekologizm, socjalizm i kapitalizm

Źródło: opracowanie własne na podstawie [Connelly 2007; Morawski 2001].

Opracowanie jakiejkolwiek teorii rozwoju trwałego wymaga konsensu trzech sił polityczno-ideologicznych reprezentowanych na rys. 3 trzema wierzchołkami trójkąta. Im konsens większy, tym obszar wewnątrz trójkąta większy. W najgorszym razie możemy mieć taką sytuację, jak w bajce Kryłowa:

Raz Łabędź, Szczupak tudzież Rak pociągnąć wspólnymi siły wóz ładowny umyśliły; lecz Łabędź rwie ku górze, Szczupak ciągnie do wody, Rak zasię z powrotem. A ten wóz jak stał, tak stoi, jakby w ziemię wrósł. Żeby z wozem ruszyć do przodu, potrzebny jest dobry woźnica.

\section{Rola organizacji międzynarodowych}

W pospolitym ruszeniu na rzecz ratowania planety czy postępu społecznego ważną rolę odgrywają organizacje międzynarodowe, takie jak ONZ, OECD, UNESCO i Komisja Europejska. To właśnie dzięki ONZ powstał Raport inicjujący ruch ,zrównoważenia”. U progu nowego Millenium na Ogólnym Zgromadzeniu ONZ w 2000 r. sekretarz generalny ONZ złożył sprawozdanie We the Peoples: The Role of the United Nations In the $21^{\text {st }}$ Century. W jego wyniku powstały dwie ważne inicjatywy. Jedna $\mathrm{z}$ nich to Millenijne Cele Rozwoju. Druga 
doniosła inicjatywa to międzynarodowy projekt Millenium Ecosystem Assessment, który ma być realizowany cyklicznie co 5-10 lat. Celem pierwszej edycji była inwentaryzacja stanu ekosystemu i jego wpływu na dobrobyt społeczny. W celu przeprowadzenia oceny stanu środowiska naturalnego zostało ono podzielone na 10 kategorii. Kategorie te są następujące: Morza i oceany, Nadbrzeża, Wody śródlądowe, Lasy, Tereny pustynne, Wyspy, Góry, Obszary biegunowe, Grunty uprawne, Aglomeracje miejskie. Do oceny dobrobytu zaproponowano sposób przedstawiony w postaci schematu na rys. 4. Część zaciemniona oznacza percepcję subiektywną jakości życia.

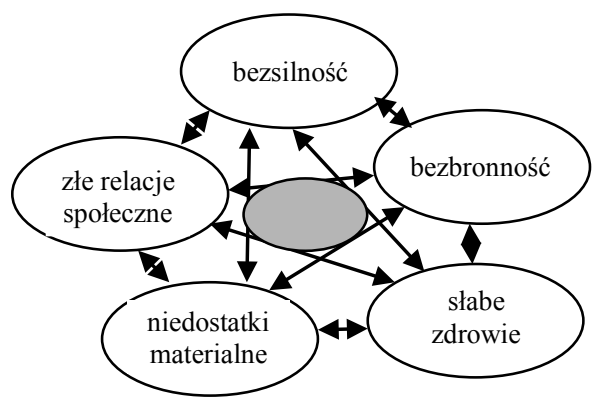

Złobyt

złe bytowanie

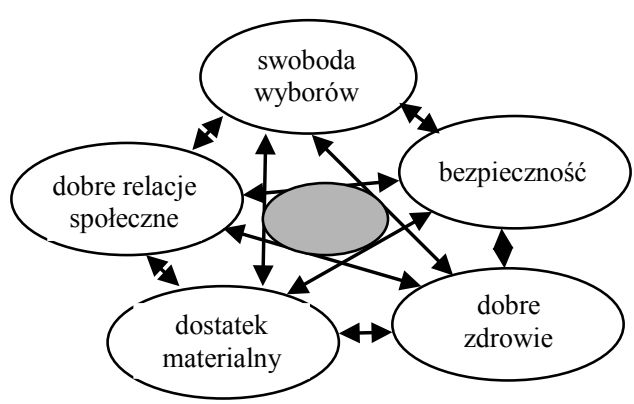

Dobrobyt

dobre bytowanie

Rys. 4. Schemat oceny dobrobytu

Źródło: [Millenium 2003].

Drugą organizacją, która bardzo aktywnie uczestniczy w ruchu na rzecz postępu społecznego jest OECD. W lipcu 2008 r. Rada OECD zaaprobowała uruchomienie Globalnego Projektu o Pomiarze Rozwoju Społeczeństw (ang. Global Project on Measuring the Progress of Societies). Projekt pomyślany był jako sieć sieci (ang. Network of networks), czyli współpracy między różnymi organizacjami różnych narodów. Realizacja projektu jest prezentowana i dyskutowana na zjazdach o ogólnym tytule Statistics, Knowledge and Policy, który jest uzupełniany podtytułem specyficznych zagadnień, którym poświęcony jest dany zjazd. Pierwsze takie Forum odbyło się w 2004 r. w Palermo, we Włoszech, w którym udział wzięło 540 ekspertów z 43 krajów, liczba uczestników była ogromna. Temat pierwszego forum był następujący: Key indicators to inform decision making. Drugie Forum (ang. Measuring and Fostering the Progress of Societies) odbyło się 
w 2007 r. w Stambule. Trzecie światowe Forum obyło się w 2009 r. w mieście Busan w Korei. Podtytuł tego Forum był następujący: Charting Progress, Building Visions, Improving Life. Czwarte Forum, Measuring Well-Being for Development and Policy Making, odbyło się w 2012 r. w Dehli.

\section{Niezrównoważoność zrównoważonego pisarstwa}

Angielskie słowo sustainability jest dobrze odbierane i prawidłowo rozumiane w językach romańskich, których podstawę stanowi język łaciński, gdyż słowo sustainability jest pochodzenia łacińskiego. Słowo to jest też prawidłowo odbierane $\mathrm{w}$ języku niemieckim, bo to Niemcy mogą się szczycić tym, że w ich języku użyto po raz pierwszy wyrazu Nachhaltigkeit, tłumaczonego pierwotnie na angielski jako lasting, później jako sustainability. W polskiej literaturze, oprócz różnorodności słowotwórczej, istnieje różnorodna fantastyka interpretacyjna. O mętniactwie i niedorzeczności pisarstwa milczeć nie można, gdyż jego autorzy należą do elity kształtującej kulturę. Młodzież nieświadoma bzdur opakowanych nadętym słownictwem, dalekim od przyzwoitej polszczyzny, przyswaja je jako naukowe i stosuje w swoich pracach (przykłady podane są niżej). Oprócz elity intelektualnej (przynajmniej za taką uchodzącą), przerażającego zachwaszczania języka i wyjaławiania kultury dokonują biurokraci urzędowi, występujący anonimowo i nie poddawani przez to żadnej krytyce. Jedni i drudzy piszą, by napisać, aby wykonać jakieś zadanie, dla jednych jest to „strategia” czegoś, którą trzeba napisać, by się wykazać, że działamy, że wykonujemy zalecenia unijne; dla drugich jest konieczność rozliczenia się z grantów. Jedni i drudzy jakby nie wiedzieli, że to, co napiszą, może być przez kogoś przeczytane. O fantastyce interpretacyjnej tego modnego pojęcia i o niechlujstwie językowym świadczą podane niżej przykłady.

Dyrektorka Forum Inicjatyw Rozwojowych, M. Skup, pisze, że „[p]rojekty wdrażane przez Forum mają na celu zwrócenie uwagi na aspekt społeczny zrównoważonego rozwoju, który podkreśla uzyskanie równowagi między rozwojem działalności gospodarczej a rozwojem człowieka w kilku płaszczyznach: ekonomicznej, przyrodniczej i społecznej” [Skup 2009].

Prezeska Forum Odpowiedzialności Biznesu stwierdza, że „wypracowany przez organizację raport Wizja 2050 to optymistyczny scenariusz, który pokazuje, jak może wyglądać przyszłość, jeśli firmy na 
całym świecie wezmą odpowiedzialność za zrównoważony wzrost naszej planety" [Wizja...].

Parlamentarzyści polskiego Sejmu też się popisali, tradycyjnie zresztą, zarówno polszczyzną, jak i inwencją w stosowaniu brzydkiego słowolejstwa. W uchwalonej, i przez Prezydenta RP podpisanej, ustawie z 2001 r. mamy tekst następujący: „Przez zrównoważony rozwój rozumie się taki rozwój społeczno-gospodarczy, w którym następuje proces integrowania działań politycznych, gospodarczych i społecznych, z zachowaniem równowagi przyrodniczej oraz trwałości podstawowych procesów przyrodniczych, w celu zagwarantowania możliwości zaspakajania podstawowych potrzeb poszczególnych społeczności lub obywateli zarówno współczesnego pokolenia, jak i przyszłych pokoleń" [Wskaźniki... 2011, s. 11].

W rankingu mętniactwa językowego i niezrównoważenia intelektualnego pierwsze miejsce zajmuje dokument rządowy o nazwie Strategia zrównoważonego rozwoju Polski do roku 2025, który opracowano w 1999 r. Niżej podane są trzy urywki z tego Dokumentu [Strategia... 1999].

„Powołana w roku 1983 pod egidą Organizacji Narodów Zjednoczonych Światowa Komisja Środowiska i Rozwoju, pod przewodnictwem Pani Gro Harlem Brutland, Premiera Norwegii, w raporcie «Nasza Wspólna Przyszłość» wyznaczyła środowisku funkcję jednej z trzech podstaw dalszego rozwoju cywilizacyjnego świata, obok gospodarki i spraw socjalnych" [Strategia... 1999, s. 7].

„W Raporcie tym pojęcie «sustainable development» zdefiniowano jako prawo do zaspokojenia aspiracji rozwojowych obecnej generacji bez ograniczania praw przyszłych pokoleń do zaspokojenia ich potrzeb rozwojowych" [Strategia... 1999, s. 3].

„Pod pojęciem rozwój rozumie się najczęściej sekwencję logicznie następujących po sobie zmian bytów, czy struktur prowadzących do osiągnięcia przez nie nowego stanu jakościowego i/lub ilościowego" [Strategia... 1999, s. 5].

Ani wyważony, ani zrównoważony komentarz takiego niechlujstwa czy nieuctwa językowego jest niemożliwy. Komentarz tego pisarstwa można pominąc chociażby $\mathrm{z}$ tego powodu, że Strategii nikt nie czyta, i czytać nie będzie. Pozostaje ona jednak jako dokument rządowego wstydu.

Na pewno potrzebna jest zaś przestroga przed innym dokumentem rządowym pt. Jak uczyć o społecznej odpowiedzialności i zrównoważonym rozwoju, wydanym wspólnie przez Ministerstwo Gospodarki, Zespół do spraw Społecznej Odpowiedzialności Przedsiębiorstw. 
Trzy lata po opublikowaniu Strategii, czyli w 2002 r. powołano Radę ds. Zrównoważonego Rozwoju złożoną z 37 prominentnych osobistości. Większość z nich to podsekretarze Stanu i ministrowie, czyli ci którym trzeba by było doradzać, stali się doradcami. O działalności tej Rady dowiadujemy się nieco z odpowiedzi Ministra T. Podgajniaka na interpelację posła $\mathrm{Cz}$. Śleziaka udzieloną mu 18 lipca 2005 r. Pełna odpowiedź zawarta na dziesięciu stronach, zawiera dwa, niżej przytoczone, zdania o tym czego Rada dokonała.

„Do niewątpliwych sukcesów Rady zaliczyć należy inicjatywę dokonania przeglądu zobowiązań Polski wynikających z postanowień zawartych w Planie działań Szczytu Ziemi w Johannesburgu (program wdrażania). Również z inicjatywy Rady przesłano do Sekretariatu Światowego Szczytu Społeczeństwa Informacyjnego (Genewa 2003) propozycje powołania - w ramach ONZ - Światowego Centrum Strategii Trwałego Rozwoju".

Inicjatywa utworzenia takiego Centrum to prawdziwe curiosum. Inicjatywę tę poprzedził równie kuriozalny Apel Warszawski - o ekorozwój (por. [Apel...]) skierowany do „wszystkich społeczeństw, rządów i elit świata". Niestety rządy i elity świata pozostały głuche na apel polskich elit, i Centrum przy ONZ nie udało się stworzyć.

W 2010 r. Radę zlikwidowano. W 2014 r. powołano zaś nową radę. Tym razem nieco mniejszą, dwudziestoosobową Radę ds. Zrównoważonego Rozwoju Energetyki, której przewodniczy J. Buzek. O działalności jej na razie nic nie wiadomo. Może znowu do czasu interpelacji jakiegoś posła.

Inne dokumenty rządowe to Strategie. Wśród dziesięciu strategii rozwoju Polski jest Strategia zrównoważonego rozwoju wsi, rolnictwa i rybactwa (SZRWRR), poza nalepką z napisem ,zrównoważony”, z trwałością rozwoju, strategia ta niewiele ma jednak wspólnego. $Z$ kolei Strategia rozwoju kapitału społecznego, która m.in. ma wesprzeć „rozwój inteligentny - wsparcie kształcenia się, szkolenia i uczenia się przez całe życie", czyli inteligentny rozwój inteligencji. Wiedzieliśmy, że inteligencję można rozwijać, a teraz wiemy także że sam rozwój może być inteligentny, zaś kształcenie może się odbywać w budynku inteligentnym (por. np. [Budynek...]).

Pomijając komentowanie takiego pisarstwa, warto zauważyć niepokojące zjawisko. Otóż nie tylko w rządowej Strategii, lecz także we wszystkich polskich pracach, które przejrzałem, autorzy powołują się na Raport Brundtlandy (a nie Pani Brutland!), wcale nie znając go, może nawet i nie wiedząc, że jest polskie tłumaczenie, bo wszyscy 
cytują wydanie oryginalne, podają zaś definicje z jakichś innych źródeł, np. z książki Rogalla. Niemiecki ekonomista H. Rogall w swojej pracy także cytuje definicję $\mathrm{z}$ Raportu Komisji, którą kierowała STATYSTYCZNY G. Brundtland, ale według tłumaczenia niemieckiego. Kolejne przetłumaczenie jej na język polski dało nie najlepszy wynik. Definicja jest niby taka sama, a jednak nie taka sama: „Trwały rozwój jest rozwojem zaspakajającym potrzeby teraźniejszości bez ryzyka, że przyszłe pokolenia nie będą mogły zaspokoić swoich potrzeb" [Rogall 2010]. Niemieckie thumaczenie jest takie: „Dauerhafte Entwicklung ist Entwicklung, die die Bedürfnisse der Gegenwart befriedigt, ohne zu riskieren, daß künftige Generationen ihre eigenen Bedürfnisse nicht befriedigen können".

Ponieważ H. Rogall uważa taką definicję za niewłaściwą, to podaje swoją własną, którą traktuje jako definicję precyzyjną: „Zrównoważony rozwój zmierza do zapewnienia wszystkim żyjącym dzisiaj ludziom i przyszłym pokoleniom dostatecznie wysokich standardów ekologicznych, ekonomicznych i społeczno-kulturowych w granicach naturalnej wytrzymałości Ziemi, stosując zasadę sprawiedliwości wewnątrzpokoleniowej i międzypokoleniowej" [Rogall 2010, s. 44]. Bez żadnego komentarza widać, jak bardzo jest ona jednak nie tylko nieprecyzyjna, lecz także mętna.

J. Zbierska wyjaśnia genezę idei na rzecz zrównoważonego rozwoju następująco: „W 1983 roku powołano Światową Komisję Środowiska i Rozwoju (WCED) Narodów Zjednoczonych, tzw. Komisję Brundtland (od nazwiska przewodniczącej Komisji - Pani Gro Brundtland). Komisja ta przygotowała dokument Nasza wspólna przyszłość, opublikowany w 1987 roku, w którym po raz pierwszy sformułowano pojęcie zrównoważony rozwój (sustainable development) zdefiniowane następująco: «Zrównoważony rozwój spełnia potrzeby obecnej generacji tak, aby nie przekreślić możliwości spełnienia potrzeb przyszłych generacjiı”" [Zbierska 2007, s. 276]. W oryginalnej wersji ta absurdalna definicja jest wythuszczona, mimo iż ujęta jest $\mathrm{w}$ cudzysłów, nie podano źródła. W polskiej wersji Raportu takiego sformułowania nie ma, być może jest to własne tłumaczenie $\mathrm{z}$ języka angielskiego.

A. Bać [2014, s. 9] analizuje różne przejawy zrównoważenia i cytuje m.in. definicję budynku zrównoważonego, jako budynku, który ,$[\ldots]$ zużywa podstawowe zasoby, takie jak energia, woda, materiały $i$ teren, bardziej efektywnie niż budynki projektowane tylko zgodnie $\mathrm{z}$ prawem". Z jej pracy dowiadujemy się ponadto, że istnieją różne sys- 
temy certyfikacji zrównoważenia budynków. Istnieje także zrównoważone projektowanie architektoniczne.

Nr 13(19)

W innej, bardzo ważnej, bo PAN-owskiej publikacji, o „specjalizacjach inteligentnych" jest dużo niezbyt inteligentnej twórczości specjalistów od specjalizacji inteligentnych. Jako przykład nich posłuży tylko ten fragment: „Historycznie rzecz ujmując, prewencyjne i oszczędne technologie w użyciu surowców i prewencyjne podejście do ochrony środowiska pojawiło się w oficjalnej polityce technologicznej różnych państw po Raporcie Rzymskim" (1972) [Donella i in. 1972]. Następnie pod wpływem Raportu Gro Brundtland [1987] Our Common Future lansującego tzw. rozwój sustensywny, podejście prewencyjne uzyskało wsparcie różnych agencji rządowych zajmujących się ochroną środowiska" [Malik (red.) 2013].

Poprzednio wyjaśniałem, że Gro to imię żeńskie, podobnie Donella jest także imieniem żeńskim, a pod imieniem nikt nie podaje swoich publikacji. Autorami raportu Klubu Rzymskiego, a nie „Raportu Rzymskiego", są następujące osoby: Donella H. Meadows, Dennis L. Meadows, Jorgen Randers i William W. Behrens III.

J. Godlewska [Skup 2009, s. 15], omawiając edukację dla zrównoważonego rozwoju (istnieje także narodowa strategia na ten temat), określa ją jako „edukację, która umożliwia uczącemu się zdobywanie umiejętności, wiedzy i cech zapewniających mu trwały rozwój”. Wśród przedmiotów nauczania zapewniających uczącemu się trwały rozwój, znajdujemy takie zagadnienia, jak: prawa człowieka, równość płci, dobre rządy, gospodarka rynkowa. Na VI Kongresie Obywatelskim, który, z udziałem Prezydenta RP, odbył się w Gdańsku w 2011 r. omawiano problemy rozwoju i edukacji, i oczywiście rozwoju zrównoważonego także. Zgodnie z podtytułem tego Kongresu (,Wielkie przewartościowanie"), przewartościowaniu poddano koncepcję rozwoju zrównoważonego. Prawdopodobnie bez minimalnej znajomości literatury dotyczącej tego, co w języku angielskim określa się jako sustainability (nie ma do niej żadnych odnośników), bazując wyłącznie na bliskoznaczności słów zrównoważenie i równowaga, podano własną, polską, interpretację tego pojęcia. Oto ona: „Pojęcie zrównoważonego rozwoju rozumiane bywa bardzo różnie, a w zderzeniu $\mathrm{z}$ problemami dotyczącymi naszego kraju uzyskuje pewien dwoisty wymiar. Nie jest bowiem w naszym przypadku głównym problemem znalezienie równowagi między wzrostem gospodarczym a wymogami ochrony środowiska, na czym skupia się główny nurt globalnego my- 
ślenia o zrównoważonym rozwoju" [Rozwój... 2011, s. 45]. Dla łatwiejszego zrozumienia wywodów na ten temat podany jest przykład. „Przykładem działania na rzecz zrównoważonego rozwoju może być STATYSTYCZNY janosikowe" [Rozwój... 2011, s. 48].

Prawdziwe przewartościowanie podane jest przez innego autora: „Zrównoważony rozwój zaczyna się w zrównoważonym człowieku” [Rozwój... 2011, s. 143]. Ten rodzaj człowieka został należycie określony: ,zrównoważony człowiek to taki, który zaspokaja trzy fundamentalne potrzeby, realizując w swoim życiu cele i wartości, które są determinowane wewnętrznie i odnoszą się do rozwoju osobistego, zakładają autonomię i szacunek do samego siebie, nawiązywanie pozytywnych i znaczących relacji z ludźmi oraz uruchomiają działania wychodzące poza bezpośredni interes własny, np. działania na rzecz dobra wspólnego (co nota bene jest warunkiem rozwoju kapitału społecznego)" [Rozwój... 2011, s. 144].

Chyba można to wszystko podsumować deklaracją inicjatora i organizatora Polskiego Forum Obywatelskiego:

„Jesteśmy bowiem przekonani, że na drodze świadomego rozwoju naszych metakompetencji możemy 'przegonić' Zachód. Nie doganiając go" [Rozwój... 2011, s. 14].

Za pomocą takiej broni jak nasze metakompetencje, świadomie rozwinięte, przegonić możemy każdego intruza, a szczególnie takiego, który by nam zechciał podrzucać kukułcze jaja w postaci ,zrównoważonego picia czy jedzenia". Oto tylko JEDNO zdanie na temat Sustainable food consumption [Reisch $\mathrm{i}$ in. 2013]: "Perhaps the most encompassing attempt is that introduced by the UK Sustainable Development Commission [2005, 2009], defining ,sustainable food and drink" as that which is safe, healthy, and nutritious for consumers in shops, restaurants, schools, hospitals, and so forth; can meet the needs of the less well off at a global scale; provides a viable livelihood for farmers, processors, and retailers whose employees enjoy a safe and hygienic working environment; respect biophysical and environmental limits in its production and processing while reducing energy consumption and improving the wider environment respects the highest standards of animal health and welfare compatible with the production of affordable food for sectors of society; And supports rural economics and the diversity of rural culture, in particular by emphasizing local products that minimize food miles". 


\section{Uwagi końcowe}

$\mathrm{Nr}$ 13(19)

Walka z określeniem „zrównoważony rozwój” jest być może bezsensowna, ale z myślą o tych, ktorzy jeszcze równoważyć nie zaczęli, a sprawa przyszłości planety i ludzkiej egzystencji na niej nie jest im obojętna, podaję kilka faktów pod rozwagę. G. Atkinson (wraz ze swoim zespołem) już w 1997 r. podał najkrótszą definicję sustainable development: development that last, nie kto inny jak K. Arrow definiuje sustainability jako: the maintaince or improvement of well being over time, A. Bartlett uważa, że w oryginalnej definicji niepotrzebnie nacisk położono na zaspokajanie potrzeb obecnego pokolenia, i dlatego proponuje nieco zmodyfikowaną definicję: sustainable development is development that does not compromise the ability of future generations to meet their own needs, bo chodzi przecież głównie o „zachowanie planety” i „utrzymania” życia na niej. Właśnie to jest najistotniejsze, aby zostawić planetę przyszłym pokoleniom w stanie nie gorszym niż nam ją przekazano. To jest cel nadrzędny. Jest nawet znane takie powiedzenie: planety nie dostaliśmy, wypożyczyliśmy ją od naszych wnuków. Nie jest prawdą, że możliwe są strategie win-win, czy nawet jeszcze dziwaczniejsze, win-win-win. Maksymalizacji zysku z działalności gospodarczej nie da się pogodzić z trwałością środowiska. Nie model trzech filarów powinien stanowić podstawę nauki o trwałym rozwoju, lecz model matrioszki, taki w którym gospodarka (ekonomia) jest tą najbardziej wewnętrzną matrioszką, podporządkowaną tym, które ją utrzymują (czyli sustain). Nie maksymalizujmy użyteczności przyszłych pokoleń, bo nie mamy ku temu prawa, nie wiemy czy one akurat pragną takiego dobrodziejstwa od nas. Użytecznością, którą chcemy im zostawić w spadku nie „zrównoważymy" ich kłopotów, którymi je obarczamy. Nie umiemy przecież poradzić sobie z utylizacją odpadów radioaktywnych, ale zostawiamy je przyszłym pokoleniom; odpadów tych zostawiamy coraz więcej, i pod wodą i zakopanych i na powierzchni ziemi. Wytwarzamy ogromną ilość syntetycznych związków chemicznych, w obrocie komercyjnym jest ich już około 100 000, a jaki mają one wpływ na zdrowie (nawet obecnego pokolenia), nie wiadomo, bo badaniu poddano zaledwie 200 związków, wszystkie one dostają się do gleby, do wody i do atmosfery. Czy Matka Ziemia poradzi sobie z nimi, jeśli tej trucizny o nieznanym nam działaniu dostaje coraz więcej? Nad tym się zastanówmy. „Po raz pierwszy w historii samo istnienie ludzkiej rasy zależy od radykalnej odmiany ludzkiego serca" [Fromm 1999, s. 47]. 
Nie mogło być socjalizmu z ludzką twarzą, niemożliwy był faszyzm z uśmiechniętą twarzą, tak samo niemożliwy jest zielony kapitalizm korporacyjny. Nie ważne ile kolektorów słonecznych zainstaluSTATYSTYCZNY je BP na swych stacjach benzynowych, to i tak wciąż jest w czołówce największych niszczycieli środowiska, na niewyobrażalną skalę. W owczej skórze wilk pozostaje wilkiem. Stać nas wszystkich na odmianę serca, nie poddawajmy więc naszych mózgów praniu, w szczególności poprzez lekturę o zrównoważonym biznesie (i przez ten biznes wydawaną!). W spisie literatury podanej niżej jest wiele prac, które można wskazać jako lekturę obowiązkową. Niestety są też pozycje, które należy omijać dalekim łukiem. Prawdą jest także i to, że ciągle są jeszcze ludzie gotowi użyć swojego mózgu w celu innym niż uzyskanie korzyści materialnych, a ponieważ artykuł niniejszy kończę pisać 22 kwietnia, to nie wypada zakończyć go inaczej jak życzeniem

Happy Earth Day!

\section{Literatura}

Apel Warszawski - O ekorozwój. Do wszystkich społeczeństw, rządów i elit Świata!, http://www.kte.psl.pl/apel.htm, (dostęp: 1.02.2015).

Arrow K., Dasgupta P., Goulder L., Mumford K., Oleson K., Sustainability and the measurement of wealth, NBER Working Paper Series, 16599, Cambridge, 2010, www.nber.org/papers/w16599 (dostęp: 31.01.2015).

Atkinson G., Dietz S., Neymayer E., Handbook of sustainable development, Edward Elgar, Northampton 2007.

Bać A., Idea zrównoważenia i jej wybrane przejawy, „Architectus” 2014, 2(38), s. 3-11.

Bailey R. (red.), The true state of the Planet, The Free Press, New York 1995.

Barlett A.A., Reflection on sustainability, population growth and environment, http://www.albarlett.org/articles/art_reflections_part_1.html (dostęp: 31.01.2015).

Berdo J., Zrównoważony rozwój. W stronę życia w harmonii z przyroda, Earth Conservation, Sopot 2006.

Bohdanowicz J., Ku cywilizacji ekorozwoju, Wydawnictwo Uniwersytetu Gdańskiego, 1998.

Bonevac D., Is sustainability sustainable?, Acad. Quest. 2010, 23, s. 84-101.

Borys T., Wskaźniki zrównoważonego rozwoju, „Ekonomia i Środowisko”, Centrum Doskonałości dla Zrównoważonego Rozwoju przy Uniwersytecie Ekonomicznym we Wrocławiu, Warszawa, Białystok 2005. www.karr.pl/pliki/csr/ (dostęp 27.06.2015).

Budynek inteligentny http://www.ue.wroc.pl/aktualnosci/7312/inteligentny_budynek centrum_ksztalcenia_ustawicznego.html\#.VY7AtFLKNZc (dostęp: 26.06.2015)

Ciążela H., Antycypacja idei „,rozwoju trwałego i zrównoważonego” w koncepcji „,nowego humanizmu” Aurelio Peccei, „Problemy Ekorozwoju” 2007, nr 2, 59-67.

Connelly S., Mapping sustainability development as contested concept, „Local Environment" 2007, No. 3, s. 259-278.

Costanza R., Cumberland J., Daly H., Goodland R., Norgaard R., An introduction to Ecological economics, St. Lucie Press and ISEE, 1997. 


SLASKI
PRZEGLAD
STATYSTYCZNY
ing and Assessment" 2003, Vol. 86, s. 19-28.

Nr 13(19) Daly H., Ecological economics and sustainable development. Selected essay of Herman Daly, Edward Elgar, 2007.

Dasgupta P., The place of nature in economic development, The Beijer Institute of Ecological Economics, Discussion Paper, 2008, No. 216.

Dodds S., Towards a „science of sustainability”: improving the way ecological economics understands human well-being, ,Ecological Economics” 1997, Vol. 23, s. 95-111.

Domka 1., Kryzys środowiska a edukacja dla ekorozwoju, Wydawnictwo UAM, Poznań 1998.

Dowbor L., Demokracja ekonomiczna, Książka i Prasa, Warszawa 2009.

Ekins P., ,Limits to growth” and „sustainable development”: grapping with ecological realities, „Ecological Economics” 1993, Vol. 8, s. 269-288.

Ekologia. Przewodnik Krytyki Politycznej, Wydawnictwo Krytyki Politycznej, Warszawa 2009.

Figuieres Ch., Tidbal M., Sustainable exploitation of natural resource: a satysfying use of Chichilinsky's criterion, Econ Theory 2012, Vol. 49, s. 243-265.

Fromm E., Mieć czy być, REBIS, Poznań 1999.

Gerwin M., Plan zrównoważonego rozwoju dla Polski. Lokalne inicjatywy rozwojowe, Earth Conservation.

Giddens A., Klimatyczna katastrofa, Prószyński I S-ka, 2010.

Haines Ch.A., Reclaiming progress by limiting economic growth, ,, Journal of Sustainable Education" 2013, Vol. 5, s. 1-11.

Hamilton K., Atkinson G., Wealth, welfare and sustainability, Edward Elgar, 2006.

Jackson T. Prosperity without growth. Economics for a finite Planet, Earthscan, London 2009.

Jak uczyć o społecznej odpowiedzialności i zrównoważonym rozwoju. Przewodnik dla nauczycieli http://bibliotekawolontariatu.pl/wpcontent/uploads/Jak_uczyc_o_CSR.pdf (dostęp: 22.04.2015)

Kiełczewski D., Dobrzańska B., Ekologiczne problemy zrównoważonego rozwoju, WSE, Białystok 2009.

Kiełczewski D., Sektor publiczny a kształtowanie wzorców trwałej konsumpcji, „Optimum - Studia Ekonomiczne" 2008, nr 4.

Kronenberg J., Bergier T. (red.), Wyzwania zrównoważonego rozwoju, Fundacja Sendzimira, Kraków 2010.

Kuhlman T., Farrington J., What is sustainability, "Sustainability" 2010, nr 2, s. 3436-3448 .

Living planet report, WWF, 2014 http://www.footprintnetwork.org/en/index.php/GFN/ page/living_planet_report2/(dostęp: 31.01.2015).

Malaska P., Kaivo-oja J., Luukkanen J., Sustainability and economic growth: a theoretical Framework and empirical demonstration, Turku School of Economics and Business administration. Finland Future Research Centre, FUTU 1999, 4/99.

Malik K. (red.), Polityka rozwoju regionów oparta na specjalizacjach inteligentnych, „PAN Komitet Przestrzennego Zagospodarowania Kraju”, Tom CLV, Warszawa, 2013.

Mazur-Wierzbicka E., Koncepcja zrównoważonego rozwoju w polskiej polityce społeczno-gospodarczej, [w:] Kopycińska D. (red.), Państwo i rynek w gospodarce, PTE, Szczecin 2003. 
Michnowski L., Odnowiona strategia trwałego rozwoju Unii Europejskiej: co z niej wynika dla Polski, „Problemy Ekorozwoju” 2008, nr 2, s. 89-128.

Millenium Ecosystem Assessment. Ecosystem and Human well-being. A framework for assessment, Island Press, 2003.

Millenium Ecosystem Assessment Synthesis Report, 2005 www.milleniumassessment.org (dostęp: 31.01.2015).

Morawski W., Socjologia ekonomiczna, PWN, Warszawa 2001.

Nasza wspólna przyszłość, PWE, 1991.

Odpowiedź ministra środowiska na interpelację nr 10304, http://orka2.sejm.gov.pl/ IZ4.nsf/main/6C6746B7 (dostęp: 31.01.2015).

Ohl B., Wolf S., Anderson W., A modest proposal: global rationalization of ecological footprint to eliminate ecological debt, "Sustainability: Science, Practice \& Policy" 2008, Vol. 4, s. 1-11

Ostasiewicz K. Quality of life and sustainable development, In Rusnak Z., Ostasiewicz K. (red.), Quality of life and sustainable development, Wrocław University of Economics, 2013, s. 9-26

Polany K., The great transformation, Beacon Press, Boston, 1965.

Polski Komitet ds. UNESCO, witryna internetowa: www.unesco.pl, (dostęp: 31.01.2015).

Poskrobko B. (red.), Teoretyczne aspekty ekonomii zrównoważonego rozwoju, WSE, Białystok 2011.

Poskrobko B., Ekonomia zrównoważonego rozwoju w świetle kanonów nauki, WSE, Białystok 2011.

Reisch L., Eberle U., Lorek S., Sustainable food consumption: an overview of contemporary issues and policies, "Sustainability: Science, Practice, and Policy" 2013, No. 2, s. 1-19, http://sspp.proquest.com (dostęp: 31.01.2015).

Rifkin J., Howard T., Entropia, nowy światopoglad, KOS, Katowice 2008.

Rogall H., Ekonomia zrównoważonego rozwoju, Zysk i S-ka, Warszawa 2010.

Rozwój i edukacja. Wielkie przewartościowanie, „Wolność i Solidarność” nr 42, IBnGR, Gdańsk 2011.

Sarkar S., Kern B., Eco-socialism or barbarism. An up-to-date critique of capitalism, Initiative Eco-Socialism, Mainz 2008.

Schumacher E. F., Mate jest piękne, PIW, Warszawa 1981.

Simms A., An environmental war economy, NEF, 2001.

Simms A., Johnson V., Chowla P., Growth isn't possible. Why we need a new economic direction, NEF, London, 2010.

Singer P., One Word. The ethics of globalization, NB, Yale University Press, 2002.

Skup M., Zrównoważony rozwój - aspekty rozwoju społeczności lokalnych, Fundacja Forum Inicjatyw Rozwojowych, Białystok 2009.

Smith R., Beyond growth or beyond capitalism?, "Real-world Economics Review" 2010, 53 , s. $28-43$

Strategia zrównoważonego rozwoju Polski do roku 2025, Ministerstwo Środowiska, Warszawa, 1999. http://www.access.zgwrp.org.pl/materialy/dokumenty/StrategiaZrownowazonegoRozwojuPolski/, (dostęp: 2.02.2015).

Umiński T., Ekologia Środowisko. Przyroda, Wyd. Szkolne i Pedagogiczne, Warszawa 1995.

United Nations Secretary-General's High-level Panel on Global sustainability, Resilient People, Resilient Planet: A future worth choosing, UN, New York 2012.

Welzer H., Wojny klimatyczne, Wydawnictwo Krytyki Politycznej, Warszawa 2010.

Wizja zrównoważonego rozwoju dla polskiego biznesu 2050, www.mg.gov.p1/files/ upload/8383/MG_WIZJA.pdf, (dostęp: 31.01.2015). 
Wskaźniki zrównoważonego rozwoju Polski, US, Katowice 2011.

Zbierska J., Geneza idei i edukacja na rzecz zrównoważonego rozwoju, „Fragmenta Nr 13(19) Agronomica” 2007, nr 4(96), s. 275-281.

Zegar J. S. (red.), Koncepcja badań nad rolnictwem społecznie zrównoważonym, IERiGŻ, Państwowy Instytut Badawczy, nr 11, Warszawa 2005.

\section{ON THE SUSTAINABLE DEVELOPMENT}

Summary: This paper is based on my Three Conference lectures about the essence of sustainable development, and the critical remarks about Polish literature devoted to this subject. In all publications examined by me authors made references to the Brundtland Report, and quoted definitions of sustainability, but they ignored the fact that this Report has been translated into Polish, and definitions are quite different. Without knowing the basic literature, and on the basis of merely their own intuition many authors gave interpretations which might be classified as fantasy. This is caused probably by the fact that the English adjective sustainable has been incorrectly translated as which means balanced.

Keywords: sustainable development, planet sustaining, critique Polish vocabulary. 